\title{
The Involvement of Women in the Production of Emping Melinjo (Melinjo Chips) to Improve the Economy of Rural Farmer Household
}

\author{
Thriwaty Arsal ${ }^{1 凶}$ \\ ${ }^{1}$ Department of Sociology and Anthropology, Semarang State University, Indonesia \\ Permalink/DOI: http://dx.doi.org/10.15294/komunitas.v7i2.4720 \\ Received : August 2015; Accepted: September 2015; Published: September 2015
}

\begin{abstract}
Women's involvement in the production of melinjo chips were related to the low educational level and less skill. They only had skill in producing melinjo chips that they inherited from their parents. Women who worked to produce melinjo chips were only to help their husband to improve their household economy. In addition, collector companies only recognized man as workers; therefore, only man who got the salary. Qualitative research was used as the research method with 10 informants consisted of men and women. Research result indicated that the involvement of women in the production of melinjo chips was marginalized where salary was not calculated despite their involvement in the whole production process. Moreover, there was no recognition for women's work and they had no health insurance and social protection from the collector companies.
\end{abstract}

Keywords: women; melinjo chips; household economy; domestic and public activities

\section{INTRODUCTION}

It seems that radical feminism movement, Marxist liberal and women studies in various approaches have similar focus and scope, which is discrimination on women in domestic and private and extra domestic or public levels (Rinaldo 2008; Panjwani 2005). In gender perspective, it is stated that the condition is existed due to patriarchy ideology internalized into the awareness structure of society that construct the perspective of women world into a masculine power framework. In turn, a sort of power-domination "man cosmology" grows with its various manifestations. In addition, gender relation is politically constructed thus masculine domination continues to grow and develop that results in a kind of colonization in term of power colonization (Hung, Yoong and Brown 2012).

In existentialism perspective, the condition takes place in dichotomy framework of women that associated to nature

\footnotetext{
Corresponding author:

Address: Kampus Sekaran, Gunungpati,Semarang 50229 Indonesia

Email : thriwatyarsal@gmail.com

Telp : 081326711018
}

and man that associated to culture (nurture) that spread and collective oriented into kinship rules should be followed (Budiman 1985). Feminism movement, however, tries to release women from this natural deterministic through androgyny education or education without gender stereotype so natural differences and gender-based work division is no longer existed (Pitt, Khandker and Cartwright 2006; Roudi-Fahimi, Moghadam 2006).

Actually, gender difference is not an issue as long as it does not cause inequality to women and man. In reality, however, gender difference has created inequality both for women and man. Gender inequality is both a system and structure and either women or man is the victim of the system. The condition is marked with the existence of role standardization causing inequality in terms of, among other, economic impoverishment process, subordination, violence against women, stereotyping, dual roles and

(C) 2015 Semarang State University. All rights reserved p-ISSN 2086 - 5465 | e-ISSN 2460-7320

UNNDS JOURNALS


marginalization (Fakih 1999; Coleman 2010; Hutchens 2010).

If women conduct their dual role, public and domestic roles, they will have no time to rest. Todaro (1998) stated that household economic work of women is almost unlimited from searching or buying, cleaning and processing or cooking raw materials, raising livestock, taking care of and cleaning the house and taking care of their children. Those activities are not unimportant even collecting wood for fuel and collecting water would require a whole day. In addition, in order to have extra income, many women involve in industrial activities and household handicraft(Tambunan 2009; Duflo 2012).

\section{RESEARCH METHOD}

The research was conducted at Desa Ngalian, Central Java, Indonesia. Research informants were married women with minimum 10 years involved in melinjo (Gnetumgnemon) chips production. The informant was determined through stratified random sampling

Qualitative research was used to describe the involvement of women in public activities, which is the production of melinjo chips to improve household economy of rural farmers, time spent, decision making in the family and marginalization experienced by women. Regarding the research, the unit of analysis was individual (men and women involved in the production of melinjo chips) assuming that individual action in deciding to do the work of melinjo chips which is methodological individualism. Qualitative data analysis was conducted on information of event and motivation basing the social action of actors involving in the production process of melinjo chips related to social action.

\section{RESULTS AND DISCUSSION}

Type of men's work is one of causal factors for women to decide to work. If a man has sufficient income to fulfill family's need, a married woman is not allowed by her husband to work including in the production of melinjo chips. In general, the men worked as farmers, farm workers and construction workers where their income was usually not sufficient. Thus, women worked to "help men" in fulfilling their family's need. One of the works chosen by women was producing melinjo chips. The work was chosen since they were educated by their husband, directly or indirectly about the work. In addition, they lacked of skill and ability to compete in formal sector. Therefore, they chose any work available and tried to fulfill their daily needs. The involvement of women in melinjo chips production for livelihood was various. Research result, however, indicates that the involvement was mostly due to skills inherited from the parents for producing melinjo chips and to help the husband to improve household economy.

The involvement of women in choosing their work as melinjo chipsmakers was because they had no other skills. The skill in producing melinjo chips was in processing melinjo into chips and it was measured from the level of chip ripeness during roasting, pressure level during hitting the melinjo, the evenness and the cleanliness of the chip and these measures determined the quality of the chip. These skills could only be gained from years of experience. An experienced craftsman needs certain feeling and art to estimate how to produce a good quality chips since the quality is not only determined by the production process.In addition, each region had certain specialty in melinjo chip production technology. The chip, however, was produced with simple technology that takes more time and workers. It was similar to the tools used by informants in research location. The simplicity of the technology was actually benefited the rural society since it absorbed labor, especially women and children.

Generally, women who worked in melinjo chips production had no special education related to their work. It meant that they worked based on their interest, talent and experience. The learning process happened during working and their skill in the chip production was gradually shaped including in raw material handling, roasting, peeling the seed's skin, thinning the seed's meat, drying and sorting.

The research indicated that working 
experience of women in melinjo chips production was various with majority had 21-25 years of experience. According to their statement, they had been working in melinjo chips production since they were single for they were ordered based by norm to be able to produce the chip and they inherited the skill from their mother or their relatives. The reason for working before and after their marriage was different. Before they married, the reason was to help their parent and after the marriage the reason was to help their husband to earn the living. Girls in the research location showed intention and participation toward the work conducted by their mother as if they had been shaped in an environment where girls should have skill like their mother for future need after they get married. Thus, working experience in melinjo chips production for women had been started since they were single.

\section{The Contribution of Income of Wife/ Women in Family}

Economic factor is a determinant for one's status in a family. Power is determined by level of income. One who gains the income will gain the role in the family. Thus, a wife having contribution in fulfilling family's need will have higher role in decision making in the family. The amount of the contribution to the household is influenced by factor of family need that different among families. A woman with low income can be considered as having high contribution to the family if the family need is low. In addition, it also influenced by type of work and man's income.

On the contrary, women with husband who has non fixed salary, such as who work at construction and farm, will be the main source for family income. However, most of them are reluctant to mention about their contribution and economic activities. If their contribution is higher than men generally they will be lower than men. As stated by Warto in Abdullah (1995, p.171) that the existence of working women is increasingly important but they have less recognition than men. They are only considered as helping the family.

With the role of women in public ac- tivities to help men to earn a living means that women have economic contribution for family prosperity. Economic contribution in melinjo chips production by gaining wage will influence family income, directly or indirectly.

For some working women, income is aimed to help family economic needs since men, as the head of the family, are generally responsible to finance the household sustainability even though some women hold the responsibility as stated by Abdullah (1997, p.200) that women as one of household element should be able to gain income.

The income distribution of working women in melinjo chips production was varied from Rp. 100.0oo,- to up to Rp. 200.00o,-. Based on child ownership, informant with the lowest income, Rp. 10o.ooo,-, was informant with toddlers. It is understandable since most of her time was used to take care household and nurture the kid and she used her remaining time for melinjo chips production. In reality, women did not receive the income and wage that supposed to be their right since the wage was used for the family members.

Informants with toddlers produced 3 $\mathrm{kg}$ chips for every 8 hours, averagely. It means, in a week they produced $24 \mathrm{~kg}$ chips and $48 \mathrm{~kg}$ for a month. If for $1 \mathrm{~kg}$ of chips they received Rp. 1.250,-; then, for $48 \mathrm{~kg}$ the income would be $48 \times$ Rp. 1.250,- = Rp. 105.000,-. Informants without toddlers, in average, produced $5 \mathrm{~kg}$ chips per day since they could do the work without being interrupted by activity of nurturing the kids and they only had domestic activities such as cooking, cleaning the house and laundry. Since domestic activities were not timeconsuming activities, they could work for melinjo chips production for 8-10 hours per day, in average.

Informants with kids at the age of 10 years or more produced $6 \mathrm{~kg}$ chips per day, in average. The informants could produce more chips because it was not only the wives who do the work but they got help from their children. In terms of allocation of income gained from melinjo chips production, some informants stated that generally the husband give all the income to the wife by 
saying "be wise in shopping and don't be lavish". According to them, in terms of income allocation women would decide the consumer need of the family and men decided on the cost for school and purchasing valuable goods and production needs such as tools for chip production for maintenance. The cost of tools damage will be burdened to the worker which is different to formal workers who will never have the burden. One of the employers in research location stated that the reason for production system to be conducted at worker's home was due to unavailability of capital to build the factory and to reduce production cost.

\section{The Role of Women in Public Activities}

Research result shows that women has big role in public activities. Public activity is any activity conducted inside or outside the house to gain income in form of money. However, women sometimes do not realize that what they do outside their domestic activities that produce money is considered as public activity. When they asked about their work and what they do, their answer is that their work is to help the husband and to taking care the family. Based on the result of interview, some informants stated that they were working and took care the family as well; whereas, in reality, they were also doing economic activity to help the husband to earn a living. Research result indicates that women contribution to the family was bigger than that of men. An informant with the help of their bigger daughter was able to gain more income than the husband who was a farm worker. The involvement of women in public activity, especially in melinjo chips production was aimed to add income from the husband and to help in fulfilling family needs.

Women with dual roles will have more time spent for domestic and public activities compare to women with only domestic activities who spent their time for nurturing the kids, cleaning the house, cooking and so on. With more time given for work, in this case to make a living, it will improve family income and prosperity.

Research result shows that informants with youngest kid of more than 10 years old and informants without toddler but having kids within the age of 5 - 10 years worked for 8 hours per day. It was found that member of the family including kid workers helped to do the work in melinjo chips production especially for family with youngest kid at the age of more than 10 years or unmarried adult children. Informants without any kids worked more than 8 hours per day since they had more time for public activities compare to informant having toddlers or smaller kids. Informants who had toddler worked $<8$ hours per day because in addition for doing public activities, they also had to divide their time for domestic activities, which is nurturing their small kids.

Based on the phenomenon, it can be seen that women had long working hours based on the time allocated by women for working to earn a living for more than 8 hours per day. Since the work in melinjo chips production could be postponed and household work cannot, women often did the work in melinjo chips production at night. During peak season such as before Eid and Christmas celebration, they could work late while other family members already went to bed.

Women from low level tend to use more time for earning a living than people in higher level with high income. It is due to their poverty where the only economic source to be relied on is their self; thus, they have to work longer to fulfill the family economic needs because their income is low/ small.

\section{The Involvement of Women in Public Activities and Economic Marginaliza- tion}

Income source from working women cannot be underestimated since almost half of the family needs fulfilled by their wage. The involvement of women in earning a living has put women in a double position, as a wife, mother and worker.

In the whole working world, women's work is undervalued and underestimated. Sometimes their work is considered invisible since it has no statistic record. Women's work is viewed as "helping" than earning an income. A myth that man earns 
a living and women is only a housewife as the best norm arrangement for human is still strongly adhered despite all proofs that show the opposite. It shows that there is less recognition toward the existence of women. In general, society states that women's place is at home. Women is not meant to earn a living because it is man's job. Even though women works and earns sufficient income, her status remains as helping the man.

An opinion that women is not the main wage earner has caused women to be invisible and neglected thus they became marginalized from waged work. It is also happened among workers in melinjo chips production in the research location. As worker, they were underestimated in terms of salary and production. Companies only considered man as waged worker.

Man beliefs that women works in the context of her family has no money compensation and is not considered as worker. Thus, women's work, in this case melinjo chips production, was neglected by labor market or company. Women suffered because the company had no respect on their work. Thus, employers could exploit women and considered them as production tools. Therefore, women were often in loss as they were positioned as the second citizen and only able to do domestic works and had no public role.

Work division based on sex means that women is considered as secondary wage earner in the family while man is the main wage earner. In reality, however, in research location, women worked longer. Since early in the morning women were busy with their work and in the end of the day no one recognized their work; whereas their economic contribution in a family was big since they were the one who did the work in melinjo chips production. In reality, they had no recognition in term of wage and no status given for their work. They received no benefit, social protection and working contract. Thus, women in research location experienced marginalization based on wage earned, which is their right from their work.

Basically, people work to earn income or wage to fulfill their family needs. Research result indicates that women worked day and night with long working hours with no recognition as worker and their status was only to help family worker with no wage and through hard work. The informants stated that they had no recognition on their work from the companies that provided raw materials and land. Although there existed work division between man and women where man nurturing and harvesting the melinjo tree and marketing the yield; women often involved in those activities, especially during harvest time. On the other hand, women's job was processing melinjo into chips. The work was considered suitable for women. In a family with daughters, the daughters would help the work of processing emping without involving the sons. The skill was inherited since employers did not provide any training. Because there was no training from the employers, worker was unable to develop. Unskilled workers will have low wage work because the risk of product damage in the production process was the responsibility of the worker.

Women involved in melinjo chips production had no bond in form of contract with employers; therefore, if they were unable to work due to sick, giving birth or else they would receive no salary. Based on interview, some informants stated that men were generally unskilled in melinjo chip production since traditionally they considered the job is women's job. As stated by Mrs. Sutami "My husband is unable to make the chips, so his job is only harvesting and nurturing melinjo tree". So, as a wife she was the one who processed the chip. Man's jobs, among other, were harvesting, taking raw materials of melinjo logs and delivered the processed melinjo chips to collectors. Instead of women, men would receive wage from the chips produced.

Based on observation in research location, it can be found that most women had the production process at their home with no men involved in the process. Melinjo is the mainstay plant of the family that continues to bear fruit because the plant blooms a whole year. Harvesting is conducted when the fruit is red in color and usually it happens twice a year. In Limpung Batang, harvesting time is conducted in April and Oc- 
tober. Melinjo plants with good cultivation process could produce $3-5 \mathrm{~kg}$ fruit per plant per year.

During harvesting time in Ngalian Village, man's role was superior based on time spent for the activity, 7 hours per day from o8:00 - 12:00. Women, on the other hand, spent 2 hours per day to help the husband during the time. The man's job was ended if the plant no longer bears fruit but women's job continued. Although the harvesting time was ended, the raw material was provided by companies thus for working women in research location they did not influenced by harvest time. They were continued to work to help the husband in earning a living in which it is conventionally the role of man. The existence of imbalanced job division between man and women could be considered as exploitation of service and resources of working women including an anomaly where the risk of product damage will be the responsibility of workers instead of employers. For employers, it was an effective and efficient way for quality control for there was no supervision during production process. As stated by Mrs. Karti "Any damage in the chips production is our responsibility as a worker where if it happens the wage given will not be full or we will receive low wage". According to one informant the employers did not recognized them as a worker thus they did not received holiday allowance. When they were unable to work because of sick, giving birth or if one of family member is sick, they would not produce the chips. Therefore, they would not receive income or wage.

In addition to income for the sustainability of their family live, women who worked to produce the chips felt the benefit of having the production process at home since they would have time to work to gain money, take care their kid and do other household works such as cooking, laundry and cleaning the house. Another problem faced by the worker was health impact experienced by women for working in long period such as various physical changes and health decline. The complaints on health were various from back pain, swollen leg, stomachache and pain in other parts of body.
Since women worked to help the husband to improve family economy and not as a worker of a company they received no health benefit and social protection. In addition, the company did not provide health facilities.

\section{Work Relationship Pattern between Women and Collectors Company of Melinjo Chips}

Working relationship pattern between women in melinjo chips production and the company shows that informant had no direct relationship with the employers. Even the workers stated that they never had any working contract with the company because the men who had direct relationship with the company.

Women who worked in the chips production were basically to help their husband whom known by the collector company as the worker as stated by Mrs. Ngatinah "I work only to help my husband. It is pretty good in helping the cost for my children's school. We want our children to have better future even though we are poor". (When asked whether women had relationship with the company that hired their husband). The informant responded that "it is man who will have the relationship with parties outside their household and who is appropriate to present in a meeting at the village or at the company, we only follow them". Thus, women who worked in the chips production to help the husband was a family worker and did not recognized as a worker in a company. Although they seemed to be an invisible worker their contribution to the family was big.

Sajogyo (1983) developed a wider and sharper conception on work in measuring the work of women consisted of: a. In work, the actors exclude energy; $b$. The actors are intertwined in social interaction and gain status; c. The actors give contribution in production in form of services and goods; $\mathrm{d}$. The actors received cash and natural income; and e. The actors gain time-value result.

Based on the work conception above, the work of taking care the household to support reproduction process in a family and the work of obtaining income in supporting the family life. 
Research result shows that women had important role in public activities in this case in producing melinjo chips, based on the time spent by women that longer than that of men. Even though women had role in public activities, it seemed they were still able to do their domestic works because based on normative aspect the activities were their responsibility as a housewife. It was possible because the nature of the activities in melinjo chips production was relatively irregular and conducted in their house (at home). Thus, women were still able to do household activities and the work to earn a living could be done along, within or after their household activities. This type of work allowed women to do other activities, such as social activities.

\section{Domestic and Social Role}

Women as a wife and housewife has responsibility for household activities thus they have to give full attention to domestic works such as cooking, laundry, house cleaning, taking care other family members. With their additional role to help their husband in earning a living means that their responsibility is heavier and it is hoped that other family members could have responsibility in conducting household works that usually do by the mother.

Based on the research result, it shows that most informants stated that women always cooked for the whole family because they had no maid. Although they had daughter in law in the house they still did the cooking themselves. This cooking activity was generally conducted before the work of chips production or within those activities; especially for informants who do the work at home. Only few informants who gave over the cooking activity to other family members such as adult children and daughter in law at home; whereas, other informants stated that their relatives or even their parents helped them in cooking activity. Although women had spent their time to help men to add family income; however, cooking is the responsibility of women as a housewife since it related to food menu arrangement that should be adjusted with the available fund from income gained by husband and wife.
Informants with 10 years old kids or above stated that their kids who did domestic activities such as house cleaning and laundry. It shows that there existed work division in the household in order to reduce working weight of the informant who could have more concentration in producing melinjo chips.

The role of women in decision making in a family was influenced by personal resources including formal or informal education, personal experience, skills and wealth (land and house ownership and others). To discuss on decision making in a family, the first thing to be done was by reviewing who the financial manager in the family is, who has the authority to determine the use of money gained by the family especially for the daily life. Financial management of the family is generally done by the wife as stated by Kustiarti in Abdullah (1997) that the important role of a woman is indicated by the fact that in most household in Java women held responsible in managing household income and expenses.

Decision making in a family can be measured through one of types i.e.: (1) decision making by wife only; (2) decision making by wife along with husband; (3) decision making by husband and wife but wife is more dominant; (4) decision making by both husband and wife equally; (5) decision making by husband only (Sajogyo 1983). Decision making in a family revealed in the research was (1) decision on determining food menu for family; (2) decision on children education; and (3) decision to buy household furniture.

Determining food menu for the family is an important role because good menu will influence the health and nutrition of family members. Based on research result, it shows that it was wife who determined food menu consumption for the family and she decided what menu to be provided to the members without having discussion with husband. It happened in all informants except few informants who had public role and had no children. The condition was supported by Javanese culture that generally considers kitchen element as women (wife) element and man is not allowed to interfere into the 
element since it will be considered offend the wife's feeling.

Some informants, however, stated that in determining food menu they often discussed with their husband or children. The final decision, however, would be in wife's hand. Since wife held the family income and managed the money for daily food needs means that decision making in money utilization for family needs will be in wife's hand as a housewife.

\section{CONCLUSION}

The involvement of working women in melinjo chips production to improve household economy was in term of wage and income gained from their work was incalculable although they involved in the whole production process of the chips. Their status was only family worker who helped their husband. Time spent by women in the production process of melinjo chips was higher, which is $>8$ hours per day. The condition of women in the production of melinjo chips was they had no health benefit and social protection from the collector companies and there was no recognition on their work both from the company and the husband. The company did not recognize women as their workers because there was no working contract between the company and women who do the production process of melinjo chips. Working contract was existed only between the company and men. With the role of women to help men in earning a living and in domestic activities means that women had dual roles, as a wife, mother of her children and wage earner. The existence of marginalization experienced by women who worked at melinjo chips production support the assumption that women in labor market are underestimated and tends to be suppressed and exploited since they are considered as cheap and unskilled labors thus they are easy to be exploited. Women are not only suffered from discrimination and gender inequality caused by gender beliefs but also experienced class suppress in a society. Women are always positioned in the second class that considers being able to do domestic works only and has no public roles.
The role of women in public activity, in this case in melinjo chips production, gave high economic contribution because it could add income from the husband and improve family economy.

\section{REFERENCES}

Abdullah, I., 1997. Sangkan Peran Gender. Pustaka Pelajar, Yogyakarta.

Budiman, A., 1985. Pembagian Kerja Secara Seksual. Sebuah Pembahasan Sosiologi Tentang Peranan Wanita di Dalam Masyarakat. Gramedia, Jakarta.

Coleman, I., 2010. The global glass ceiling: Why empowering women is good for business. Foreign Affairs, pp.13-20.

Danim, S., 2004. Metode Penelitian untuk Ilmu-Ilmu Prilaku. Bumi Aksara, Jakarta.

Duflo, E., 2012. Women empowerment and economic development. Journal of Economic Literature, 5o(4), pp.1051-1079.

Fakih, M., 1999. Analisis Gender dan Transformasi Sosial. PustakaPelajar Offset, Yogyakarta.

Hung, A., Yoong, J. and Brown, E., 2012. Empowering women through financial awareness and education. OECD Working Papers on Finance, Insurance and Private Pensions, (14), pp.1.

Hutchens, A., 2010. Empowering women through fair trade? Lessons from Asia. Third World Quarterly, 31(3), pp.449-467.

Mocan, N.H. and Cannonier, C., 2012. Empowering women through education: Evidence from Sierra Leone (No. w18016). National Bureau of Economic Research.

Panjwani, A., 2005. Energy as a Key Variable in promoting gender equality and empowering women: A gender and energy perspective on MDG\# 3 . Department for International Development, United Kingdom.

Pitt, M.M., Khandker, S.R. and Cartwright, J., 2006. Empowering women with micro finance: Evidence from Bangladesh. Economic Development and Cultural Change, 54(4), pp.791-831.

Rinaldo, R., 2008. Envisioning the nation: Women activists, religion and the public sphere in Indonesia. Social Forces, 86(4), pp.1781-1804.

Ritzer, G., 2003. Sosiologi Ilmu Pengetahuan Berparadigma Ganda. Rajawali Press

Roudi-Fahimi, F. and Moghadam, V.M., 2006. Empowering women, developing society: Female education in the Middle East and North Africa. Al-Raida Journal, pp.4-11.

Sajogjo, P., 1983. Peranan Wanita Dalam Perkembangan Masyarakat Desa. Rajawali Press, Jakarta.

Tambunan, T., 2009. Women entrepreneurs in Indonesia: Their main constraints and reasons. Journal of Asia Entrepreneurship and Sustainability, 5(3), pp.37.

Todaro, M.P., 1997. Economic Development in The Third World, Sixth Edition. Longman Limited, London.

Weber, M. 1964. Social Action and Types. Editor Talcott Parsons. The Free Press New York. 